\title{
What Sticks with First Year Engineering Students and Engineering Faculty in STEM Education Service-Learning Projects?
}

\section{Jennifer Ocif Love, Northeastern University}

Jennifer Love is a member of Northeastern University's Gateway Team, a group of teaching faculty expressly devoted to the First Year Engineering Program at Northeastern University. The focus of this team is on providing a consistent, comprehensive, and constructive educational experience that endorses the student-centered and professionally-oriented mission of Northeastern University.

\section{Dr. Susan F Freeman, Northeastern University}

\section{Daniel Sullivan, Center for STEM Education, Northeastern University}

BSCE Northeastern University 2011 Magna Cum Laude Candidate for Masters in Urban and Regional Policy, Northeastern University 2014 Center for STEM Education, Program Coordinator from 2009 Engineers Without Borders, Honduras Design Lead and NE Regional Workshop Coordinator EIT, MTEL Certification 


\title{
What Sticks with First Year Engineering Students and Engineering Faculty in STEM Education Service-Learning Projects?
}

\begin{abstract}
In this qualitative assessment of a pilot program spanning 3 semesters, two (2) College of Engineering faculty at Northeastern University explored and managed several experiential service-learning projects in their first-year engineering courses between Fall 2012 - Fall 2013. As a result of 84 first-year engineering students working with 7 different community partners, 215 middle school and high school students were exposed to engineering curriculum through meaningful service-learning projects involving STEM (science, technology, engineering \& mathematics) education that they otherwise would not have received. The service-learning projects were qualitatively very successful in delivering STEM curriculum to young students, as determined from faculty observations and from the first-year engineering students' own observations and feedback about their experiences. As a result of faculty members' experiences, observations and reflections, 15 success factors have been identified for first-year engineering students and engineering faculty to consider before implementing meaningful service-learning engineering projects in an urban community. The purpose of this paper is to share these 15 success factors with other engineering educators who may be considering STEM education service-learning projects in their curriculum, especially those who will be initially managing the projects all by themselves. "What Sticks" refers to what has been successful and meaningful for both the first-year engineering students and the engineering faculty.

Introduction

Many of today’s first year engineering students enter Northeastern University with memorable community service experiences from their hometowns which inspire them to pursue similar opportunities in college. As a result, faculty in the First Year Engineering Program at Northeastern University developed service-oriented design projects (not direct service-learning projects) as part of a required first-year engineering course that have a similar impact in demonstrating the connection between engineering and the community as experiential servicelearning projects do. ${ }^{1}$ However, the gains associated with a hands-on direct service-learning project were encouraging enough for faculty in this study to visit a pilot year of experiential service-learning projects in their first-year engineering courses. Similar experiences by engineering faculty at other universities confirms that the motivation for faculty to pursue service-learning pedagogy in their own engineering courses originates from the faculty's desire to increase student motivation to learn, to enhance students' ability to solve real world problems and to engage with community partners. ${ }^{2}$
\end{abstract}

As a result of implementing service-learning engineering projects in the local community over a 3-semester time period, we have confirmed that managing experiential service-learning projects requires significant additional efforts by the motivated faculty members. This was not a surprising conclusion. However, building a team of engineering students who wish to continue in the following years as service-learning mentors alleviates some of the additional challenges on the faculty member and allows for the program to become more sustainable. This paper presents 
qualitative evidence from the students and faculty to support 15 success factors in 4 key areas for first-year engineering students, engineering faculty and their service-learning partners to consider before implementing meaningful STEM education service-learning projects in an urban community. This advice is especially relevant for engineering faculty who will be initially managing the service-learning projects all by themselves without any formal engineering service-learning programs supporting the initiative.

\section{Background}

By definition, service-learning integrates community service with academic learning. Jacoby and Associates in 1996 defined this pedagogy as "a form of experiential education in which students engage in activities that address human and community needs together with structured opportunities intentionally designed to promote student learning and development". ${ }^{3}$ Examples of traditional engineering service-learning projects include designing and building a community playground, a small footbridge or boardwalk along a nature trail or a computer lab in a senior citizens center. Jacoby also emphasized that "reflection and reciprocity are key concepts of service-learning". ${ }^{3}$ Service-learning in engineering has also been shown to meet Accreditation Board for Engineering and Technology (ABET) objectives. ${ }^{4}$ Particular student outcomes such as (c), (d), (f), (g), (h), (i), (j) and (k) can be mapped to results and tasks in engineering servicelearning projects (Table 1 ).

Table 1. ABET Student Outcomes. ${ }^{5}$

(a) an ability to apply knowledge of mathematics, science, and engineering

(b) an ability to design and conduct experiments, as well as to analyze and interpret data

(c) an ability to design a system, component, or process to meet desired needs within realistic constraints such as economic, environmental, social, political, ethical, health and safety, manufacturability, and sustainability

(d) an ability to function on multidisciplinary teams

(e) an ability to identify, formulate, and solve engineering problems

(f) an understanding of professional and ethical responsibility

(g) an ability to communicate effectively

(h) the broad education necessary to understand the impact of engineering solutions in a global, economic, environmental, and societal context

(i) a recognition of the need for, and an ability to engage in life-long learning

(j) a knowledge of contemporary issues

(k) an ability to use the techniques, skills, and modern engineering tools necessary for engineering practice.

As a result, several engineering educators have already established successful service-learning programs with first-year engineering students at other universities. ${ }^{6,7,8}$ Some service-learning projects for first-year engineering students even involve K-12 outreach. ${ }^{9}$ According to Thompson and Oakes, "the integration of a pre-college outreach program and the first-year learning communities in engineering and science has been a successful partnership”. 9

\section{Methods}

During the Fall 2012, Spring 2013 and Fall 2013 semesters, two faculty members in the First Year Engineering Program offered STEM service-learning projects to over 300 first-year 
engineering students who were enrolled in a required Engineering Design course . Eighty-four (84) first year engineering students actually elected to fulfill one of their course requirements with an engineering service-learning project involving middle or high school students in the Boston community (Table 2).

Table 2. Examples of Service Learning Partners \& Projects

\begin{tabular}{|c|c|c|c|c|c|c|}
\hline & Partners by Project & Semester & Description & $\begin{array}{c}\mathrm{K}-12 \\
\text { Students }\end{array}$ & $\begin{array}{c}1^{\text {st }} \text { Year } \\
\text { Engineering } \\
\text { Students }\end{array}$ & $\begin{array}{l}\text { Outcomes \& } \\
\text { Deliverables }\end{array}$ \\
\hline 1 & $\begin{array}{l}\text { Sociedad Latina } \\
\text { (Roxbury, MA) }\end{array}$ & Fall 2012 & $\begin{array}{l}10 \text { week after school } \\
\text { program in an urban } \\
\text { community near NU }\end{array}$ & $\begin{array}{l}60 \\
6^{\text {th }}-8^{\text {th }} \\
\text { graders }\end{array}$ & 24 & $\begin{array}{l}\text { STEM lesson } \\
\text { teaching by } \\
\text { engineering students } \\
\text { with careers/majors }\end{array}$ \\
\hline 2 & $\begin{array}{l}\text { Latino STEM Alliance } \\
\text { (Greater Boston) }\end{array}$ & Fall 2012 & $\begin{array}{l}\text { Lego Textrix \& Lego } \\
\text { NXT Mindstorm } \\
\text { Robotics curriculum for } \\
\text { high school students }\end{array}$ & $\mathrm{n} / \mathrm{a}$ & 4 & $\begin{array}{l}\text { Written STEM } \\
\text { curriculum only (no } \\
\text { active teaching by } \\
\text { engineering students) }\end{array}$ \\
\hline \multirow{4}{*}{3} & $\begin{array}{l}\text { Yawkey Boys \& Girls } \\
\text { Club (Roxbury, MA) }\end{array}$ & Fall 2012 & $\begin{array}{l}\text { Evening program, } \\
\text { LEGO NXT Mindstorm } \\
\text { Robotics curriculum }\end{array}$ & $\begin{array}{l}10 \\
3^{\text {rd }}-8^{\text {th }} \\
\text { graders }\end{array}$ & 8 & $\begin{array}{l}\text { STEM lesson } \\
\text { teaching by } \\
\text { engineering students }\end{array}$ \\
\hline & $\begin{array}{l}\text { Blue Hills Boys \& } \\
\text { Girls Club } \\
\text { (Dorchester, MA) }\end{array}$ & Fall 2012 & $\begin{array}{l}\text { Evening program, } \\
\text { LEGO NXT Mindstorm } \\
\text { Robotics curriculum }\end{array}$ & $\begin{array}{l}10 \\
3^{\text {rd }}-8^{\text {th }} \\
\text { graders }\end{array}$ & 8 & $\begin{array}{l}\text { STEM lesson } \\
\text { teaching by } \\
\text { engineering students }\end{array}$ \\
\hline & $\begin{array}{l}\text { Yawkey Boys \& Girls } \\
\text { and Blue Hills Boys \& } \\
\text { Girls Clubs }\end{array}$ & $\begin{array}{l}\text { Spring } \\
2013\end{array}$ & $\begin{array}{l}\text { Evening program, } \\
\text { LEGO NXT Mindstorm } \\
\text { Robotics curriculum }\end{array}$ & $\begin{array}{l}15 \\
3^{\text {rd }}-8^{\text {th }} \\
\text { graders }\end{array}$ & $\begin{array}{l}5 \text { volunteers } \\
\text { repeat from } \\
\text { Fall } 2012\end{array}$ & $\begin{array}{l}\text { STEM lesson } \\
\text { teaching by } \\
\text { engineering students }\end{array}$ \\
\hline & $\begin{array}{l}\text { Yawkey Boys \& Girls } \\
\text { and Blue Hills Boys \& } \\
\text { Girls Clubs }\end{array}$ & Fall 2013 & $\begin{array}{l}\text { Evening program, } \\
\text { Hexbug Nano \& new } \\
\text { Lego EV3 Robotics }\end{array}$ & 25 & 10 & $\begin{array}{l}\text { STEM lesson } \\
\text { teaching by } \\
\text { engineering students }\end{array}$ \\
\hline \multirow{3}{*}{4} & \multirow{3}{*}{$\begin{array}{l}\text { Citizen Schools \& } \\
\text { Orchard Gardens } \\
\text { Elementary School } \\
\text { (Roxbury, MA) }\end{array}$} & Fall 2012 & $\begin{array}{l}\text { “Alternative Energy } \\
\text { Vehicles”, } 10 \text { weeks, } \\
\text { extended school day }\end{array}$ & $\begin{array}{c}20 \\
6^{\text {th }} \text { graders }\end{array}$ & 4 & \multirow{3}{*}{$\begin{array}{l}\text { STEM lesson } \\
\text { teaching by } \\
\text { engineering students }\end{array}$} \\
\hline & & $\begin{array}{l}\text { Spring } \\
2013\end{array}$ & $\begin{array}{l}\text { "City of Engineers", } 10 \\
\text { weeks, extended school } \\
\text { day }\end{array}$ & $6^{\text {th }}$ graders & 4 & \\
\hline & & Fall 2013 & same as Fall 2012 & $\begin{array}{c}20 \\
6^{\text {th }} \text { graders }\end{array}$ & 4 & \\
\hline 5 & $\begin{array}{l}\text { Machine Science \& } \\
\text { Hurley Elementary } \\
\text { School (Boston, MA) }\end{array}$ & $\begin{array}{l}\text { Spring } \\
2013\end{array}$ & $\begin{array}{l}\text { In-school STEM } \\
\text { lessons on electricity }\end{array}$ & $\begin{array}{c}20 \\
5^{\text {th }} \text { graders }\end{array}$ & 3 & $\begin{array}{l}\text { Electrical circuits } \\
\text { STEM lesson } \\
\text { teaching by } \\
\text { engineering students }\end{array}$ \\
\hline 6 & $\begin{array}{l}\text { TechBoston \& } \\
\text { Dearborn Elementary } \\
\text { School (Boston, MA) }\end{array}$ & $\begin{array}{l}\text { Spring } \\
2013\end{array}$ & $\begin{array}{l}\text { In-school LEGO NXT } \\
\text { Mindstorm STEM } \\
\text { curriculum }\end{array}$ & $\begin{array}{l}15 \\
6^{\text {th }}-8^{\text {th }} \\
\text { graders }\end{array}$ & 3 & $\begin{array}{l}\text { STEM lesson } \\
\text { teaching by } \\
\text { engineering students }\end{array}$ \\
\hline \multirow[t]{2}{*}{7} & $\begin{array}{l}\text { Boston Building } \\
\text { Resources } \\
\text { (Boston, MA) }\end{array}$ & Fall 2013 & $\begin{array}{l}\text { Redesign an office and } \\
\text { retail area for building } \\
\text { materials that are sold at } \\
\text { reduced prices. }\end{array}$ & $\mathrm{n} / \mathrm{a}$ & 12 & $\begin{array}{l}\text { STEM lesson } \\
\text { teaching by } \\
\text { engineering students }\end{array}$ \\
\hline & & & & Total 215 & Total 84 & \\
\hline
\end{tabular}


Regardless of their choice, all first year engineering students who elected a service-learning project followed the engineering design process as covered in their Engineering Design course to design, create, deliver and subsequently improve their own STEM curriculum as part of a substantial team design project. They submitted the same engineering design assignments to their professor during the semester as their peers who were working on service-oriented design projects. At the end of the semester, the first year engineering students prepared their own service-learning presentation for their classmates and a technical final report for their professor to meet their engineering course requirements, just as their peers had done for their serviceoriented design projects. Examples of service-oriented design projects included personal homeless shelters, a way to prevent dolphins from beaching themselves on Cape Cod, and wearable health monitoring systems. The difference between a service-oriented and a servicelearning design project is that the service-oriented design project is only a design on paper while the service-learning design project is actually designing and implementing a deliverable.

Of these 84 students, five (5) continued on as volunteers in a subsequent semester to extend their service-learning project by continuing to collaborate with the engineering faculty member. Except for some infrastructure support from Northeastern University's Center for Community Service and the College of Engineering's STEM Center for Education, all aspects of the servicelearning projects were managed by the two engineering faculty members.

Results

As a result of 84 first-year engineering students working with 7 different community partners over 3 semesters, 215 middle school and high school students were exposed to engineering curriculum through meaningful service-learning projects involving STEM education that they otherwise would not have received. Although a comprehensive survey was not administered to collect feedback from all 215 students or their teachers involved with the programs, the servicelearning projects were qualitatively very successful in delivering engineering curriculum to young students, as determined from faculty observations and from the first-year engineering students' own observations and feedback about their experiences.

As a result of faculty members' experiences, observations and reflections, the following 4 areas cover 15 success factors for first-year engineering students and engineering faculty to consider before implementing meaningful service-learning engineering projects in an urban community:

A. Project Choices \& Community Partners

B. Working with First-Year Engineering Students

C. Sustaining the Projects and Partners

D. Sustaining your Effectiveness as Service-Learning Engineering Faculty

\section{A. Project Choices \& Community Partners}

\section{Partner with an organization that already has on-site teaching and/or administrative support.}

The emphasis is on partnerships. Some examples are already-established afterschool programs that your students can easily insert themselves, such as Citizen Schools or Boys and Girls Clubs. If there is a local science museum nearby, they may have a program that 
could incorporate a team of students to run a specific activities or series of activities. One word of caution: some organizations are looking for the faculty and engineering students to do all the work, including designing, scheduling, running the program, finding participants and an appropriate venue, classroom management, resources and funding, etc. First-year engineering students will be overwhelmed if the entire responsibility of running the program is not supported by a partner organization. Otherwise, the burden of responsibility will be transferred to the faculty member.

2. Allow your engineering students to choose a service-learning project to fulfill one of their scholarship or service requirements, if they are so motivated.

Provide your first-year engineering students with choices in selecting a service-learning project as this will help to drive their interest, motivation and commitment to the project's objectives. Universities have scholarships and other programs requiring service so if your projects can overlap with these, it can provide a sustainable source of partners, long term involvement and much easier scheduling for the students.

3. Start every service-learning project with a theme (transportation, robotics, alternative energy, health, security, etc.). Align your service-learning projects with topics from Engineering Grand Challenges to help first year students connect with their majors.

Many students select service-learning projects such as robotics because they are interested in robotics themselves or because it relates to their major. Some engineering students are motivated by making an impact and by inspiring younger students in ways they may not have experienced when they were younger. Some of the reasons our first-year engineering students decided to pursue a service-learning design project were: "I have experience mentoring and tutoring", "I was part of a similar program in high school”, "I like working with kids as I have already been a mentor in a school”, "I would like to get out and actually do engineering instead of studying all the time", "Teaching would be a new experience that I am excited about", "teaching is a fantastic opportunity for a project to have real-world impact", and "I think showing kids how fun engineering can be is a great idea". In addition, new engineering fields such as renewable energy, health, sustainability and engineering entrepreneurship are popular for young students and their university student mentors, which may attract more participants.

4. Assign groups of 4 or more engineering students per service learning team, as appropriate, and restrict the number of younger students in the partner organization to 20 or less. Smaller teacher/student ratios are preferred.

The better the ratio, the more connections will happen for everyone involved. Younger students will be much easier to work with, will enjoy the experience more and potentially be more motivated to learn and inspired if they really get to know the university students. The university students will be able to see their impact, and have fun with the students in a positive and meaningful way. When there are too many younger students, and too few engineering students, the service-learning activity becomes chaotic. Effective classroom management may degrade and both groups may get frustrated. What may stick with engineering students is NOT to do that again, possibly with feelings of failure, 
discouragement and ineffectiveness. One engineering student wrote "I didn't enjoy the days when the kids were a bit more restless and unwilling to participate and learn”.

\section{B. Working with First-Year Students}

5. Establish clear learning objectives for your engineering students so they can directly relate their service-learning experiences back to what they are learning in your engineering course. Use journals or other written assignments to help your engineering students reflect on what they observed, learned and improved.

Clear learning objectives that directly relate the service-learning project to the coursework is required by all service-learning projects but can get lost in K-12 STEM-curriculum projects. Some of the engineering students commented that their design project was great service, but did not involve enough aspects of the engineering design process. One engineering student wrote: "some of the classroom assignments did not apply to our project so there was a disconnect there". Another engineering student wrote "I think future service-learning groups would benefit from course assignments that are more tailored towards curriculum design than physical design”. Linking the service to the course's objectives can take extra effort to keep the students aligned but the end result is a compelling acknowledgement that the engineering design process can be used to engineer just about anything.

6. Improve the effectiveness of your students' interactions with the younger students by setting up at least 8-10 on-site sessions.

Building relationships and real connections takes time. There are many examples of university students doing projects where there is a one-time event. These can be successful, and accomplish a goal. However, many of our students commented informally that they felt that it was important to get to know the students by attending multiple sessions in order to make a difference in those young students' lives.

7. Debrief and discuss each on-site experience with your engineering students immediately afterward so they can acknowledge their successes and address any failures or improvements before next week's lesson.

These are some of the best teaching moments when failures can be turned into successes. Immediate reflection can help the lessons learned stick with the engineering students. One strategy that has been successful is to have the engineering students generate solutions to problems that they have witnessed, and if possible, have them implement the problem solutions next time. For example, if the younger students are overly disruptive in one particular seating pattern, ask the engineering students to create new seating charts. Or if a lesson failed for some reason, ask the engineering students to improve the activity and try it again, as part of the engineering design process.

8. Assign female engineering students, if possible, to serve as mentors to younger female students in the partner organization.

Building relationships may also require special arrangements in other ways. In our experiences, young female students in the partner organization have undoubtedly connected with one of the female engineering students in every service-learning project. The younger 
female students look forward to interacting with the female engineering student, and are not happy if that female engineering student is absent. When the younger female students have had a rough day, some time with that "special friend" can make a huge difference. This can have a very powerful effect. Many projects have had all male engineering student teams, but when you can have a few female engineering students, it improves the effectiveness with more of the younger students, even with the boys.

\section{International and urban engineering students connect well with urban middle school} students. It's a "win-win" for both the international engineering student learning about American culture and for the middle school student learning about international culture.

For the same reasons of having female students, having a diverse multi-cultural team can be equally effective for those involved. Young urban students seem to connect well with international college students, regardless of the university student's nationality. For obvious reasons, domestic university students who have grown up in a city also connect well with young urban students. Depending on the STEM partner, some understanding of the differences in cultural backgrounds is important. In a recent semester, the engineering student team visiting a local city school had one member from Saudi Arabia, one from Kuwait and one from Serbia. They attended an orientation for the site that provided specific knowledge and demographics of that school which proved to be invaluable toward their ability to relate to the younger students. In addition, the faculty member, who also attended the on-site school orientation, got to know the university students well enough to bridge gaps and find connection points such as similar experiences or similar gaps in their knowledge so that they can relate to the young students. For example, in some countries, there is very little hands-on work done in the classroom, so the faculty member had to step in and help the international engineering students model how to design and test hands-on projects for the middle school students. The international students related well and participated more in the activities knowing that they had not had such an opportunity and brought good enthusiasm and encouragement.

\section{Sustaining the Projects and Partners}

\section{Reuse your STEM lessons with different audiences of middle school students.}

Developing new curriculum can be time-consuming and when working with middle school students, the activities and lessons really need to be tested. So even if it means that it limits how much design and creativity your university students will have, reusing your STEM lessons in several service-learning projects can save a lot of time and problems. One example is having a few lessons pre-planned, and having the engineering students be helper teachers. This shows the engineering students what is contextually appropriate for middle and high school students and what to expect in a classroom environment. Then allow the engineering students to design and plan some of the next lessons with faculty guidance. 


\section{Develop promising first year engineering students into mentors and leaders for the following year and for the remainder of their academic career, either as a volunteer, work study or paid teaching assistant.}

After a successful service-learning semester, capture that euphoric feeling and talk about how great it would be to have that group return the next semester or year. If a team of engineering students has really coalesced, they will want to build on those bonds with each other and with the faculty member. Emphasize that they have done the design and testing, and can now be peer mentors and advisors to the next group of service-learning students. The new students working with an upperclass service-learning mentor often aspire to be that mentor themselves someday. This helps to create a program that the faculty member can manage and advise, instead of bearing the full responsibility of the service-learning project by him/herself.

This strategy has sustained several partnerships and projects for many years. For example, 5 of the original 8 students who did a service-learning design project in the Fall 2012 semester at the Blue Hills Boys and Girls Club continued as volunteers at the Club in the Spring 2013 semester. Therefore, first-year engineering students who continue after their service-learning projects can create a STEM “pipeline” of volunteers at the University's STEM Center for Education who continue as STEM ambassadors in the same or other on-campus and offcampus outreach programs.

\section{Assess the effectiveness of your service learning projects among the middle school students and your engineering students to demonstrate the value of your service learning program to your colleagues and administrators.}

Documenting the effectiveness of the service-learning projects in both groups of students will support future engineering service learning projects and even acknowledge the value of service learning faculty efforts in the faculty performance review process. Generating reports and data that demonstrate the projects and their impact are valuable for faculty, for the college, for administrators, for STEM centers, for the K-12 programs and more.

\section{Sustaining your Effectiveness as Service-Learning Engineering Faculty}

\section{Become actively involved on-site to model effective teaching strategies and classroom management techniques for your engineering students.}

Time invested by the engineering faculty member in the beginning of the service-learning project and during the first on-site visits can really pay off. The more you set the expectations and standards, the more your university students will follow them. There was an investment by the faculty member in learning more about classroom management strategies from the partnering organization. This investment really paid off by using a few techniques and sharing them with the engineering students. Previous students also developed some helpful guidelines that were shared among their teams. For example, in the second year, when a university student was volunteering to serve as a mentor, he was asked to prepare a one-page document on his experiences of working with middle school students. After condensing and revising, this document has been shared with all new service learners to help prepare them for their encounters, and it has elicited discussion and new approaches when needed. This on-site involvement is crucial for the early weeks and with certain 
service-learning programs. Once the university students become more comfortable on their own and can lead the next lessons by themselves, faculty presence can be intermittent and confirming.

\section{Ask questions by involving your institution's education specialists and service learning experts in the projects. Use already established programs to support service learning training of your engineering students.}

It can be surprising how much is already available in terms of service-learning training and support. Resources such as joining ongoing programs, looking for experts from your university and partnering with other faculty and staff in similar programs can be extremely valuable toward sustaining an engineering service-learning program. An ongoing partnership with your university's STEM outreach or STEM Center for Education can link students to partnering schools or organizations, even after the service-learning project is complete. One example is working with the STEM Center staff on curriculum ideas and allowing the university students to see what types of projects and curriculum are already being used in K12 STEM outreach. The STEM Center staff can provide advice, materials and guidance, and are another voice of experience to guide them besides their faculty member. This is often a powerful and useful way to partner with your own university colleagues and their resources.

\section{Meet regularly with your service learning teams to plan the upcoming on-site lesson or activity. Attend each on-site interaction, if possible, or designate an upperclass mentor to attend in your place.}

Depending on the service-learning project and the depth of your engineering service-learning program, this can be modified accordingly. However, any project with little to no involvement from the professor can veer off the course and service-learning objectives. Without week-to-week guidance, the university students will be reluctant to admit there is a problem, and will attempt to soldier on, only allowing the problems to get worse. Meetings and attending the actual lessons or activities are time-consuming for the service-learning faculty member but are necessary in the beginning. Even if you have a trusted upperclass mentor who can meet with several engineering student groups for planning purposes, still try to personally attend and meet your engineering students as often as your schedule will allow.

\section{Discussion}

As with any service-learning project, "a significant portion of the learning in service-learning takes place when students spend time thinking about and discussing their service experience and how it relates to their coursework." ${ }^{10}$ As part of their course requirements, the first-year engineering students were asked to reflect on their experiences by writing a few paragraphs addressing several questions about their service-learning design project: What did you learn most about the engineering design process? What did you learn most about you as an engineer? What did you enjoy most about your design project? What did you enjoy least? Do you feel that you experienced a real-life engineering project through your Design Project? Did your servicelearning project have any impact on your decision to continue studying engineering or on your choice of major? The following is a sampling of positive accolades that our first-year engineering students wrote as they reflected on their service-learning projects: 
Over the course of the service-learning design project, I truly learned how to apply the engineering design process which will definitely help the concepts stick longer than if I had only just memorized them from a textbook.

It was gratifying to teach kids.

The service-learning project reinforced how fun engineering is.

I enjoyed using the design process to create STEM curriculum and to find solutions.

My Citizen Schools service-learning project compelled me to use the engineering design process quite often.

The Machine Science service-learning project taught me responsibility of being an engineer.

I enjoyed giving back to the community that I came from.

The most rewarding part of our project was putting together modules for the children and actually watching them learn.

The best part about our design project was getting to work with the kids at the Dearborn School.

I had a blast designing the circuits for the windmill project and love being around people who care about engineering as much as I do. I'm glad our team's project turned out and feel lucky that we had the chance to implement it in a Boston Public School.

My experience with the service-learning curriculum project was very rewarding. I enjoyed the opportunity to get off campus and interact with the Boston community in a way that I otherwise would not have been able to do.

In particular I feel that this is a valuable program because I truly did understand the engineering design process more by thinking through how to use it in teaching younger students.

The most fulfilling part of the project was teaching others with less advantages than I have had in my life. This was very rewarding.

I really enjoyed being in the class with the students - especially when something clicked or they appeared to be genuinely enjoying their time learning.

Each course assignment pertaining to the use of the engineering design process was applicable to my team's Citizen Schools service-learning project. I learned how to better apply the engineering design process through my project.

I personally enjoyed the topic that I had chosen as my design project: STEM education at the Hurley School because I was able to work with students and actually implement the project I was designing.

My favorite part about our service-learning design project was being able to actually implement our Citizen School's curriculum at the Orchard Gardens School. Overall, the project provided a fulfilling experience for me and allowed me to understand the engineering design process to a greater extent. 


\section{Conclusions}

Most service-learning experts encourage new programs to obtain some kind of monetary support from the college or department to maintain and sustain the program. ${ }^{4}$ This is the goal and the best approach to a well-run program. If that support is limited, then finding a way to maintain service-learning without burning out is the goal. It must be a passion, something that the faculty member is compelled to do because of who they are. Yet even that passion can be extinguished if pushed too hard. This advice comes from such a place, a faculty member that sought this elusive support at a time when the University had other priorities. Since service-learning does not pull in large research grants, there was limited success in obtaining funding for a formal engineering service-learning program, despite the success of this pilot program. Consequently, these methods were developed in order to provide an ongoing set of programs. These are now in their fourth year, with a number of students staying involved as mentors and upperclass volunteers that team up with the first-year engineering students. The plan is to continue, and if college support is increased, more programs can be developed.

Service-learning projects with undergraduate engineering students at Northeastern University will continue to thrive, especially with the effective on-campus and community partnerships that have helped this informal program impact the lives of 84 engineering students and 215 local children in a little over 1 calendar year. As more engineering faculty discover the benefits of service-learning projects in engineering curriculum, the number of students and local communities impacted will certainly increase.

\section{Bibliography}

1. Freeman, S.F., Jaeger, B.K., Whalen, R. "Service-Learning vs. Learning Service in First-year Engineering: If We Cannot Conduct First-Hand Service Projects, is it Still of Value?”. Proceedings of the American Society of Engineering Education Annual Conference, Vancouver, British Columbia, Canada, First Year Programs Division, 2011.

2. Tucker, B.G. et al., "Faculty Perspectives on Service-Learning in Engineering Education: Challenges and Opportunities”. Proceedings of the American Society of Engineering Education Annual Conference, Atlanta, Georgia, 2013.

3. Jacoby, B. and Associates, Service-Learning in Higher Education: Concepts and Practices. San Francisco, CA: Jossey-Bass, 1996.

4. Tsang, E., editor, Projects That Matter: Concepts and Models for Service-Learning in Engineering, American Association for Higher Education, 2000.

5. ABET, Criteria for Accrediting Engineering Programs - Effective for Reviews during the 2013-2014 Accreditation Cycle, 27 October 2012, 22 March 2014, <www.abet.org>.

6. Oakes, W., Coyle, E., and Jamieson, L., "EPICS: A Model of Service-Learning in an Engineering Curriculum”. Proceedings of the American Society of Engineering Education Annual Conference, 2000. 
7. Oakes, W. and Thompson, M. "Integration of Service Learning into a Freshman Engineering Course”. Proceedings of the American Society of Engineering Education Annual Conference, 2004.

8. Duffy, J., Tsang, E. and Lord, S. "Service-Learning in Engineering: What, Why and How?". Proceedings of the American Society of Engineering Education Annual Conference, 2000.

9. Thompson, M. and Oakes, W. "Using Service-Learning to Integrate K-12 Outreach into a First-Year Engineering Program”. Proceedings of the American Society of Engineering Education Annual Conference, 2006.

10. Moffat, J. and Decker, R.. "Service-Learning Reflection for Engineering: A Faculty Guide.” Tsang, E., editor, Projects That Matter: Concepts and Models for Service-Learning in Engineering, American Association for Higher Education, 2000. 